\title{
THE STATUS OF ABORIGINAL LAND RIGHTS IN AUSTRALIA
}

\author{
PHIIIP E. CHARTRAND * \\ Interesting parallels and comparisons can be drawn between the struggle for land rights by \\ Australian Aborigines and by Indians and Inuit in Canada. Recent Australian federal \\ legislation has recognized some aboriginal rights to lands they have occupied for over \\ 40,000 years. The author discusses the events leading up to that legislation, analyzes its \\ major provisions and assesses its applications to date.
}

Un "Australia Day", January 26, 1977, the Australian government proclaimed the coming into effect of the Aboriginal Land Rights (Northern Territory) Act, $1976 .{ }^{1}$ In so doing, the government reversed an aboriginal policy of 200 years standing, and, for the first time since white "discovery" of the continent, created a mechanism allowing Aborigines to gain full legal recognition of at least some of their traditional claims to land ownership in the country they have inhabited for over 40,000 years. ${ }^{2}$ What happened in 1977 was the culmination of a policy process which can be traced back a decade or more and owes much to the policy stance taken by Australia's Labour Government from 1972 to 1975 - and even more to the unremitting efforts of a handful of whites and Aborigines. But the 1977 date marks a watershed in Australia's national aboriginal policies; hence it is appropriate to focus on the legislation brought into force on that day in order to assess the extent of the legal and political reversal both in statutory terms and in terms of statutory implementation since that date.

\section{CHANGING POLICIES TOWARDS ABORIGINES}

Despite Eighteenth and Nineteenth Century insistence in official government statements that a policy of paternalism would "improve" the Aboriginal until he could take his place with the new settlers, paternalism in actuality "quickly gave way to a mixture of contempt and fear which no doubt helped excuse the more or less conscious destruction of Aborigines and aboriginal society whenever they stood in the way of the white man's material needs or desires". ${ }^{3}$ The Aboriginal was deemed so primitive with his lack of clothing, wheeled transport, writing, settled agriculture, even tents

- LL.B. (Harv.), Ph.D. (Syracuse); Associate Professor of Law, Potomac School of Law, Washington, D.C. Presently on leave of absence from Potomac, he is a Visiting Professor at the Government Affairs Institute of the U.S. Office of Personnel Management. Professor Chartrand is joint author with L. W. Holborn and Rita M. Chartrand of Refugees: $A$ Problem of Our Time, The Work of the UN High Commissioner for Refugees, 1951-1972 (1975) 2 vols.

1. (Commonwealth) No. 191 of 1976.

2. The Act applies to land in only one of Australia's seven political subdivisions, the federally administered Northern Territory, and only applies to restricted portions of that territory; but its passage was intended to spark similar action by the six state governments; see the speech by the Minister for Aboriginal Affairs in 99 C.P.D. H. of R. 3081-84 (June 4, 1976).

3. Coombs, "Aboriginal Australians 1967-1976: A Decade of Progress?" (Walter Murdock Memorial Address at Murdock University, Perth, West Australia, Nov. 19, 1976) 2. See also Hasluck, Black Australians (1942) for a summary of Australia's aboriginal policies from 1829 to 1897; and Rowley, The Destruction of Aboriginal Society (1970) for a comprehensive survey of the country's aboriginal policies. 
or huts, that it was commonly assumed that contact with the vastly superior European culture would lead to his extinction. As in the United States and in Canada at roughly the same period, the native peoples of Australia were gathered together in the latter part of the Nineteenth Century on government-created reserves situated on land no one else wanted at the time. Unlike the North American Indians, however, the Aborigines were seen as no physical threat to white society; rather they were separated for their own protection until, due to their very backwardness, they should die out. The phrase used at the time to describe official policy was that of "smoothing the pillow" of the dying race.

But the aboriginal population, while declining in numbers, clung to life. By 1911, special protective laws to regulate relations between settlers and Aborigines were in existence throughout Australia, restricting aboriginal movement, prohibiting the consumption of alcohol, regulating employment; and this legal regimen was to grow more comprehensive until the 1940's. Aboriginal Protection Boards in New South Wales, Victoria, and South Australia, and departments of native affairs in Queensland, Western Australia, and the Northern Territory were able to control contact to some extent and to segregate a portion of the aboriginal population in reserves, often in communities administered by mission societies. Elsewhere, Aborigines eked out an existence in urban slums subject to the same kinds of discrimination experienced by Blacks in the United States in the same period, or lived a communal life of sorts at the suffrance of cattle station owners in the vast Australian Outback. However, in sharp contrast to Indian policy in the United States, aboriginal affairs remained purely a state responsibility under the terms of the Australian constitution. The Commonwealth government played a role in funding and coordinating state efforts regarding Aborigines after 1936, but it would require an amendment to the federal constitution before the central government would legislate specifically for Aborigines. ${ }^{4}$

As it became clear that the time of extinction was retreating rather than approaching, and that the number of part-Aborigines in particular was growing and their problems becoming ever more visible, there emerged two new policies for Aborigines: one for members of those traditional communities still living on reserves and a second policy for those who had drifted from their traditional ways but were excluded from settler society. In the first attempt to develop a uniform aboriginal policy nation-wide, the Australian government convened a conference with state officials in 1937 at which it was agreed that the policy aim for "the natives of Aboriginal origin but not of the full blood" was their "ultimate absorption". Varying degrees of continued

4. The Australian Constitution, like the U.S. Constitution, created a federal government of limited powers, but unlike its model, it specifically prohibited the exercise of any federal authority over "the aboriginal race in any state"; Commonwealth of Australia Constitution Act, Art 41(XXVI). While the U.S. Constitution makes reference to Indians only as part of the federal power to regulate interstate and foreign commerce, this and the treaty-making power were held by Marshall C. J. to "comprehend all that is required for the regulation of our intercourse with the Indians", Worcester v. Georgia, 31 U.S. 350 at 379,6 Pet. 515 at 559 (1832). Dicta from Marshall's opinion in Cherokee Nation v. Georgia, 30 U.S. 1 at 9, 5 Pet. 1 at 12 (1831), suggesting a guardian-ward basis for federal authority was incorporated in the holding of later Supreme Court cases, as was Marshall's argument from Johnson and Graham's Lessee v.McIntosh, 21 U.S.(8 Wheat.) 240 at 259,261 (1823), that federal authority was inherent in the federal government's ownership of the lands occupied by Indian tribes, United States v. Kagama, 118 U.S. 375 at 380, 383-84 (1886). 
segregation were contemplated for the "uncivilized" and "semi-civilized" Aborigines found mostly in the northern and central portions of the continent. ${ }^{5}$ For many Aborigines the 1937 policy harked back to that enunciated by Australia's first governors; once again special laws or programs were justified as temporary measures until "absorption" was completed. This policy objective suggested in part that "idle paupers" of aboriginal descent and dependent upon government aid could someday become fully productive members of a single Australian society. By 1951, at another national conference, the word "assimilation" had been adopted as the aim of policy towards all Aborigines. ${ }^{6}$

While the policy objective changed, the administration of aboriginal affairs and its underlying legal structure remained remarkably constant from the late Nineteenth Century until the 1960's. Increasing amounts of money were spent in areas such as education and health, but not enough to achieve stated purposes. It was not until the early 1950's that expenditures on health finally ended the absolute decline of the Aboriginal population in the north and centre of the continent. Until less than twenty years ago, separate legal and administrative systems existed in the six States and in the federallycontrolled Northern Territory "which accorded most Aboriginals a status similar to that of children and subjected them to the kinds of controls imposed on the criminal and the insane". Aborigines were not accorded the right to vote until 1962 (it is still not mandatory for them to vote as it is for white Australians); special legislation for Aborigines was not abolished in the Northern Territory until 1964.

A most exceptional event occurred in Australia in 1967, however, which would have a considerable effect upon aboriginal policy and affairs: over $90 \%$ of the national electorate approved an amendment to the federal constitution enabling the Commonwealth government to legislate on behalf of Aborigines. ${ }^{8}$ The event was particularly stunning in that the electorate, "traditionally as reluctant to say 'yes' as any Victorian maiden", has rejected roughly $95 \%$ of all amendments proposed to the constitution over the past seventy-five years. ${ }^{\theta}$ No study has been undertaken to explain why this amendment was greeted so sympathetically by the voters, but it has been suggested that it reflected a popular desire to right past injustices and provide minimally equal treatment - a companion amendment allowed Aborigines to be included in the census for the first time. One government sponsored report gives credit for "selling" these constitutional amendments of 1967 to the Federal Council for the Advancement of Aborigines and

5. Commonwealth of Australia, Dept. of Aboriginal Affairs. Report of Activities for the Period 19 Dec. 1972 - 30 June 1974 (1974) 4.

6. Id..

7. Id. at 5 .

8. The Constitution Alteration (Aboriginals) Act 1967 (No. 55 of 1967)s. 2, altered the powers of the federal Parliament as set forth in the Commonwealth of Australia Constitution Act, by striking out a limiting phrase as follows:

Art. 51. The Parliament shall, subject to this Constitution have power to make laws for the peace, order, and good government of the Commonwealth with respect to: ... (xxvi.) The people of any race, other than the aboriginal race in any state, for whom it is deemed necessary to make special laws ... [Italicized words were struck out].

9. Coombs, supra n. 3 at 1. 
Torres Strait Islanders. ${ }^{10}$ This unofficial body of Aborigines and whites, formed in 1957, had spoken out repeatedly for a change in government policies. In any case, the government of the day seems to have done little to promote the Referendum since the overwhelming vote "came as a complete surprise to most people and certainly to the then Prime Minister Harold Holt". ${ }^{11}$ It would take the appearance of a different government in Canberra before any federal legislation was enacted based on the new constitutional authority, but in the meantime aboriginal matters gained increasing national attention, and aboriginal rejection of the policy of assimilation became increasingly evident.

As a response to the 1967 Referendum, the Commonwealth Government set up an Office of Aboriginal Affairs within the Prime Minister's Department in late 1967, and Prime Minister Holt asked a group of academics knowledgeable about Aborigines to establish an advisory Council for Aboriginal Affairs in the same year. Both these bodies and a growing number of academics reported in the following years on aboriginal conditions and aspirations; aboriginal spokesmen began to appear and speak out; and both white and aboriginal thinking was affected by Black demands for equal treatment in the United States.

The first real break in the governmental policy of aboriginal assimilation came on "Australia Day" in 1972 when one of Holt's successor's as Prime Minister, William McMahon, announced that:12

The Government recognizes the right of individual Aborigines to ef fective choice about the degree to

which, and the pace at which, they come to identify themselves with [Australian] society ....

McMahon still assumed that assimilation would in time result, for he went on to say that "the concept of separate development as a long-term aim is utterly alien to these objectives" ${ }^{13}$ Nonetheless, the existence of a freedom of choice had been recognized for the first time. ${ }^{14}$ But the limited degree of this policy shift and the continued expectation of eventual assimilation can be seen from the fact that the McMahon Government refused to provide the essential ingredient necessary if aboriginal groups were to remain outside the mainstream of Australian society: i.e., legal recognition of their traditional claims to land.

\section{FIRST STEPS TOWARD A LAND POLICY}

The land policy of the federal government in 1972 continued to be that expressed two years previously: Aborigines might once have had "a long association with a particular piece of land", but that did not mean that "Aboriginals of the present day have the right to demand ownership of it". If Aborigines wanted land, they "should secure land ownership under the system that applies to the Australian community and not outside it". ${ }^{15}$ As re-

10. Commonwealth of Australia, Committee of Inquiry (Hiatt Committee), The Role of the National Aboriginal Consultative Committee (1976), as cited in Rowley, A Matter of Justice (1978) at 225.

11. Coombs, supra n. 3 at 1.

12. McMahon, "Australian Aborigines: Commonwealth Policy and Achievements" (Statement made in Canberra on Jan. 26,1972 ) at 3.

13. Id. at 4.

14. See Coombs, supra n. 3 at 5.

15. Statement by Minister of the Interior Peter Nixon, Sept. 3, 1970, cited by Pittock, "Aboriginal Land Rights" in 2 Racism: The Australian Experience (Stevens ed. 1972) at 201. 
stated by the Prime Minister in January 1972, "general purpose leases" would be granted to aboriginal individuals, groups or communities, over land in the Northern Territory's Aboriginal Reserves, but no attempt would be made $^{16}$

to translate the Aboriginal affinity with the land into some form of legal right under the Australian system [because] to do so would introduce a new and probably confusing component, the implications of which could not clearly be foreseen ....

To appreciate the significance of the land issue to Aborigines, one has to remember that every aspect of aboriginal traditional culture is grounded on a complex and very particular relationship with a specified area of land, and especially with certain sacred sites on that land. In short, land rights are the bedrock on which traditional aboriginal culture and society are built; it is impossible to conceive of a traditional aboriginal life pattern surviving apart from its roots in the land. Australian Aborigines believe that at the beginning of time every part of the continent was parcelled out to a particular aboriginal clan to become the focus of that clan's existence; yet until 1972 the settler government (unlike its North American counterparts) steadfastly refused to legally recognize any aboriginal claim to land. No treaties ceding land to settlers were ever drawn up, no statutes were ever passed to require compensation for the taking of aboriginal lands; and even the established Reserves were government-owned and administered for the benefit of the aboriginal inhabitants at the government's pleasure.

Quite apart from the economic dependence upon the land, a need which may require aboriginal groups to search for food and water over miles of the arid desert that characterizes so much of the continent, each clan has religious ties binding it to a particular area. A common descent group of men with their families are responsible for the performance of rituals at particular times and places on that land. The ritual ties do more than give meaning to their lives, they believe them to be essential to life itself. Hence, communal land ownership for the Aboriginal does not mean the right of various members of a familial group equally to cultivate a jointly held piece of land, but rather a timeless and enduring spiritual relationship, consisting of rights and duties, linking an area of land to a group of people composed of members long dead and members still unborn as well as members now alive. ${ }^{17}$

Given the aboriginal view of their relationship with land, which has no close parallels in European law and which our use of terms like "owners" does little to clarify, there could be no real opportunity for tradition-oriented aboriginal groups to choose to stay aloof from the mainstream of Australian society unless their tie to the land was somehow legally recognized. And even for those Aborigines whose traditional ties had become attenuated or lost by years of residence away from their clan lands, the recognition in law of aboriginal land claims had strong emotional and symbolic significance as an admission by the dominant society of past wrongs done. For some urban or peri-urban Aborigines, such legal recognition suggested that, in time,

16. McMahon, supra n. 12 at 9.

17. The relationship between Aborigines and land is particularly difficult to explain in Western terms since it is not dependent upon some concept of land occupancy or use. For a thorough discussion of its complexities, see the opinion of Blackburn J. in Milirrpum and Others v. Nabalco Pty. Ltd. and the Commonwealth of Australia (1971) 17 F.L.R. 141, [1972-73] A.L.R. 65. 
compensation might be paid to all Aborigines for the loss of an entire continent that once had been theirs. ${ }^{18}$

The first organized political expression of an aboriginal demand for recognition of traditional land rights occurred in 1963 when the Yirrkala people of Arnhemland in the far northeast corner of the Northern Territory objected to the federal government's granting of a license to mine upon their traditional lands. Their protests, written on bark and carried to the federal legislature in Canberra, led to a parliamentary inquiry and endless rounds of debate and publicity, but not to recognition. Finally in 1968, the Yirrkala brought suit against the mining company and the government, seeking judicial support for their contention that as traditional owners of the affected land they had the right to decide whether or not it would be mined. Mr. Justice Blackburn of the Northern Territory Supreme Court issued his opinion as trial judge in the case of Milirrpum et al. v. Nabalco Pty. Ltd. and the Commonwealth of Australia three years later ${ }^{19} \mathrm{He}$ devoted 132 pages to detailing the legal bases in both aboriginal law and Western law for the Yirrkala people's claims, but concluded that the kind of recognition given to "native title" by British, American, New Zealand, and Canadian courts was based on laws peculiar to those countries and not part of the common law applicable in Australian courts. ${ }^{20}$

Despite its significance, Justice Blackburn's opinion was never appealed. Rather, in early 1972, aboriginal groups turned their attention to the Parliament in Canberra once again, demanding major changes in national policies relating to Aborigines, most especially an end to discrimination, a greater political voice in their own future, and a recognition of their traditional claims to land. Instead of submitting a petition as before, a delegation came in person as an "Aboriginal Embassy" and camped out in numbers on the parliamentary lawn. ${ }^{21}$ Prime Minister McMahon, while officially ignoring the "Embassy", recognized the impact of the Milirrpum decision: his January 1972 speech gave Milirrpum as the reason for his cabinet's review and alteration of Aboriginal policies. But, as already noted, there was no giving way on the issue of traditional land claims.

The "Embassy", however, was to have greater success in winning over the opposition Australian Labour Party to its demands. After a meeting with demonstrators at the "Embassy" on February 9, 1972, Mr. Gough Whitlam, leader of the Opposition, pledged that a Labour Government, if elected, would reverse McMahon's rejection of "communal ownership for traditional purposes" and instead establish "community ownership of land in the Northern Territory by identifiable communities or tribes by way of freehold title".

18. Rowley, supra n. 10 at 9. An attempt by one aboriginal spokesman, Paul Coe, to claim legal title to the whole of Australia on behalf of its aboriginal inhabitants, and $\$ 20$ billion for its wrongful taking, has not yet proved successful; see Coe v. Australia and Another (1977) 18 A.L.R. 592, (1979) 24 A.L.R. 118, [1979] A.C.L.D. 216.

19. 17 F.L.R. 141.

20. Several authors have criticized one or more sections of the opinion, but all have agreed that in consequence Aborigines could expect no help from Australian courts in making tradition-based claims to land on the continent, see e.g., Hookey, "The Gove Land Rights Case" (1972) 5 Fed. L. Rev. 85; Lester and Parker, "Land Rights: The Australian Aborigines Have Lost a Legal Battle, But..." (1973) Alta. L. Rev. 189; Priestley, "Communal Native Title and the Common Law" (1974) 6 Fed.L.Rev. 150.

21. The best account of the "Embassy" and its land claims is found in Harris, This Is Our Land (1972). 
Whitlam also pledged to use the federal government's power to legislate for Aborigines so as to ensure that state Acts which discriminated against them were overturned. ${ }^{22}$

It is significant to note as well what was not included in this new pledge. Neither then nor subsequently has an Australian party leader pledged to create a new aboriginal land policy applicable to the six Australian states, despite undoubted constitutional authority to do so granted by the 1967 constitutional amendment. The new authority has been used very sparingly and then only on the basis of state cooperation, and to prevent especially blatant racial discrimination against Aborigines by the state government of Queensland. ${ }^{23}$ Aboriginal land policy has been a topic of federal legislation only with reference to the Northern Territory (still at least formally administered by the federal government in Canberra), and plenary authority to govern there existed long before the 1967 Referendum. ${ }^{24}$ Government officials in Canberra have often said that they "hoped" the states would follow the lead of the federal government in this matter. In fact, as we shall see, it would be more accurate to say that the federal government has in many ways followed the states' lead, at least with respect to the method used for regularizing aboriginal communal ownership of land in conformity with prevailing Australian concepts of property law.

The Australian Labour Party won the general election of December 1972, and immediately implemented its aboriginal policy by upgrading the Aboriginal Affairs Office to ministerial level so as to "assume the ultimate responsibility for Aboriginals and Islanders accorded [the federal government] by the Referendum of 1967". ${ }^{25}$ In the following year, agreements were entered into with all the state governments, save Queensland, to transfer state functions of health, welfare, education and housing for Aborigines to the new federal department, and to absorb the relevant state employees into the federal structure. ${ }^{26}$ Federal revenues would now flow in much larger amounts directly to or for aboriginal groups in the form of grants.

22. See Australian Labour Party, "Aboriginal Affairs Policy" (1973) at 1.

23. The Aboriginal Affairs (Arrangements With the States) Act, Commonwealth of Australia, 1 Acts of Parliament 1901-1973 57 (No. 115 of 1973) allowed the federal Department of Aboriginal Affairs to take over state functions of welfare, health, education, and housing as these affected Aborigines, but only with state consent. The Aboriginal Land Fund Act (no. 159 of 1974) established a federal government fund for the purchase of freehold or lease. hold title to land anywhere in the country for the benefit of Aborigines. The Racial Discrim. ination Act 1975 (No. 52 of 1975) outlawed discrimination on the basis, inter alia, of race in public accommodation, housing, employment, etc. The Aboriginal Councils and Associa. tions Act 1976 (No. 186 of 1976) allows for groups of Aborigines to constitute themselves as corporate entities so as to enter into contracts with government agencies and private businesses. The Aboriginal Development Commission Act 1980 (No. 34 of 1980) replaces the Aboriginal Land Fund and other statutory bodies holding and dispensing government funds for Aborigines with a new single federal authority. And two acts were specifically directed at Queensland: the Aboriginal and Torres Straits Islanders (Queensland Discrim. inatory Laws) Act (No. 75 of 1975) and the Aboriginal and Torres Strait Islands (Queensland Reserves and Communities Self-Management) Act (No. 11 of 1978). On the status of Aboriginal Reserves in Queensland, see Nettheim, (1979) 2 U.N.S.W.L.J. 314.

24. See Commonwealth of Australia Constitution Act, Art. 122.

25. Dept. of Aboriginal Affairs, Report for 1972-74, 1.

26. Aboriginal Affairs (Arrangements With the States) Act 1973 (No. 115 of 1973). 


\section{THE ABORIGINAL LAND RIGHTS COMMISSION}

With reference to land, the new government in early February 1973 announced the establishment of a single-member Royal Commission on Aboriginal Land Rights, consisting of Mr. Justice Albert E. Woodward, who had two years previously been chief counsel for the Yirrkala people in their unsuccessful fight to win judicial recognition of their land rights in the Milirrpum case. ${ }^{27}$ The terms of reference given to Woodward made plain that the government had already decided to turn over to aboriginal ownership the federally held Aboriginal Reserves in the Northern Territory, and simply wanted to know how best to do so; that it was prepared to recognize aboriginal claims to certain other lands in the Northern Territory based on traditional claims of right and interest, and wanted to know how to do this as well. Woodward was expected to return with a report and draft legislation. Despite the Commission's title, it was with one exception to concern itself only with aboriginal land issues in the Northern Territory, covering at most $20 \%$ of the country's total aboriginal population. ${ }^{28}$

Justice Woodward's first report, dated July 1973 , identified a number of problem areas, set out the relevant facts, and made a number of suggestions.$^{29}$ In particular, it suggested that a scheme might be created for vesting freehold title to reserves in legally incorporated aboriginal community groups in the Northern Territory. The report's only specific recommendation was that the federal government create two Aboriginal Land Councils in the Northern Territory to advise the commissioner on aboriginal views prior to his final report. Woodward went considerably beyond his mandate, however, by proposing that the proposed Aboriginal Land Councils be permanent creations with somewhat independent financial resources and significant political powers to negotiate now and in the future with the government on behalf of all Aborigines in the Territory. The Land Councils, in short, would continue to exist even if Woodward's land proposals were to fail. The Labour Government accepted the report, the two Land Councils were created, and the latter advised Woodward how to reply to the original terms of reference set for him. ${ }^{30}$

Woodward's second and final report was submitted on May 3, 1974, and was accepted in principle by both Government and Opposition when it was debated in the federal Parliament on July 17 th $^{31}$ Three major recommenda-

27. Woodward had been sounded out for this post in December 1972 at the suggestion of $\mathrm{Dr}$. Herbert C. Coombs, a founding member of the partisan Council for Aboriginal Rights and an adviser to Gough Whitlam both in office and out. Given Woodward's previous employment (paid for, oddly enough, by government funds), he was a natural choice for a government that had already decided on a pro-aboriginal land policy. It was Woodward's own suggestion that he be the sole member of the Commission in order to avoid dissent over the text of the final report.

28. Figures regarding aboriginal population and its distribution vary considerably, but about one-half of the pastoral Aborigines, those still living in the traditional relationship with the land, are probably to be found in the Northern Territory.

29. Aboriginal Land Rights Commission, First Report (1973).

30. The federal government even financed the provision of independent legal assistance to the Land Councils to assist them in this function; see Dept. of Aboriginal Affairs, Report for 1972-74 at 9 .

31. Aboriginal Land Rights Commission, Second Report, Parliamentary Paper No. 69 (1974) (hereafter Woodward, Second Report). 
tions stand out in this report. First, that the land needs of rural Aborigines be immediately provided for by granting them title in fee simple to the aboriginal reserves in the Northern Territory and to nine additional large areas including two pastoral station leaseholds already purchased for Aborigines by the government. Second, that Aborigines be permitted to lay claim, based on traditional affinities with the land, to additional tracts of unalienated Crown land in the Territory. Such claims were to be made on their behalf by the appropriate Land Council, and a government appointed Aboriginal Land Commissioner was to weigh such claims and make recommendations to the government concerning the transfer of land title where warranted. Twentyone extensive tracts of unalienated Crown land were to be frozen until the traditional claims could be prepared by the Land Councils and heard by the Land Commissioner. Third, that an Aboriginal Land Fund Commission be created and provided with government funds so as to purchase pastoral leaseholds to meet aboriginal needs irrespective of traditional claims. ${ }^{32}$ Woodward rejected the North American "solution" of awarding compensation to native peoples instead of land. That was no answer, he said, for a people who wanted "to maintain their separate identity in the future" ${ }^{33}$

Certainly the most intriguing aspect of Justice Woodward's Second Report was his recommendation of a statutory landholding mechanism seeking to take account of both Aboriginal and Western concepts of "title". Taking into consideration how very different traditional aboriginal landholding areas are from those of modern Australia (and elsewhere), and yet how fundamental they are to the survival of traditional aboriginal culture, Woodward adopted a submission made by counsel to the Northern Land Counsel recognizing traditional ties - but without defining or codifying them! Actual title to each major parcel of land deeded to Aborigines would be held by a separate Land Trust, an incorporated body consisting of a small number of aboriginal elders appointed by the federal government. ${ }^{34}$ The trust was perpetual in nature, since the land deeded could not be sold except to another Aboriginal corporation, and then only with the consent of its beneficiaries. And the trust was relatively specific, with its beneficiaries being said to be those Aborigines having traditional interests in or rights over the land held in that trust. ${ }^{35}$

Woodward defined traditional aboriginal owners of land in words that

32. The idea of an Aboriginal Land Fund did not originate with Woodward - it had already been pledged by Whitlam during the election campaign of 1972; see Australian Labour Party, "Aboriginal Affairs Policy" (1973) at 2.

33. Woodward, Second Report, supra n. 31 at 10.

34. The land trust idea was not a new one either. It had been pioneered in Australia by the state of South Australia in 1966, and followed by similar action in Western Australia (1972) and New South Wales (1973). The state of Victoria moved in a somewhat different direction in 1970 by turning over the ownership of its two remaining aboriginal reserves to corpora. tions consisting entirely of their aboriginal residents. These actions provided an important measure of aboriginal control of their own lands, but the single statewide trusts were viewed by many Aborigines as little different from the white controlled state agencies which had preceded them.

35. Woodward, Second Report, supre n. 31 at 12-15, 23. 
would be incorporated verbatim into the eventual legislation: ${ }^{36}$

... in respect of an area of land, a local descent group of Aborigines who have common spiritual affilia. tions to a site or sites within that area of land, which affiliations place the group under a primary spiritual responsibility for that site or sites and for that land, and who are entitled by Aboriginal tradition to forage as of right over that land.

This "definition" neatly avoided specifying what any of its terms meant, and who or how (and on the basis of what kinds of evidence) such a definition would be applied. Presumably the aboriginal elders serving on the Land Trust would know the identity of those Aborigines who were the land's "traditional owners". They would also presumably know who was an Aboriginal, since with equal circularity Woodward and the Land Rights Act would "define" an Aboriginal as "a person who is a member of the Aboriginal race of Australia" (s. 3(1)). Even today, the federal Department of Aboriginal Affairs has trouble applying this definition. In practice they use what might be called the they-must-know-each-other test that is highly dependent upon asking the leaders of known aboriginal groups whether or not the particular individual is an Aboriginal. ${ }^{37}$ Nonetheless, the term's significance lay in the fact that whoever were the "traditional aboriginal owners" of a parcel of land thereafter would have a definable and legally enforceable interest therein; and this interest had been provided for without having to translate traditional land concepts into totally dissimilar Western property terms.

It is easy enough to criticize this device for recognizing without specifying "primitive law" ideas in Western legal terms, because it has already become necessary in practice for Western judges to interpret and apply traditional aboriginal legal concepts so as to determine whether and to what extent a successful "traditional claim" has been made to a piece of vacant Crown land. At best, Woodward's attempt to avoid a tricky problem only postponed its solution. The problem is certain to worsen as, for example, mineral royalties to "traditional aboriginal owners" increase, making such identification financially rewarding. However, there was no preferable alternative. To ignore the traditional owners entirely, as preceding approaches had done, would hardly satisfy the demands being made by aboriginal groups across the country. To attempt direct deeding of the land to the traditional owners would have required a laborious determination of their identities before any land could be passed, and would have failed to distinguish between the differing kinds of traditional rights held with respect to the same portion of

36. Id. at 162. Compare Aboriginal Land Rights (Northern Territory) Act 1976, s.3(1)(No. 191 of 1976).

37. Compare the difficulties experienced by U.S. courts in defining who is an Indian. When the question was one of federal jurisdiction, the Supreme Court sidestepped a definitive answer, concluding no more than that "many individuals who are racially to be classified as 'Indians' " are nevertheless not Indians subject to federal jurisdiction, Morton v. Mancari 417 U.S. 535 at 553 n. 24 (1974); but "enrolled members" of federally recognized Indian tribes are "Indians" for federal purposes, United States v. Antelope et al. 430 U.S. 641 at 646 n. 7 (1977). The Supreme Court has refused to intervene, however, in the tribal procedures used for determining who is a tribal member, Santa Clara Pueblo v. Martinez 436 U.S. 49 (1978). 
land. ${ }^{38}$ Even the statutory use of the term "groups" turned out to be too specific since the Attorney-General's Department ruled that the membership of the "group" must be specified before the reserves could be deeded, leading to delay in implementing Woodward's primary recommendation until September 1979 after the 1976 Land Rights Act had been amended..$^{39}$

\section{NEW GOVERNMENT, NEW POLICY}

Of Woodward's recommendations, the one which was implemented in the shortest time was the aboriginal land fund. ${ }^{40} \mathrm{By} 1974$ both Government and Opposition were pledged to the utilization of federal funds to purchase leases or freehold title to land for Aborigines in the Northern Territory or elsewhere. With regard to traditional land claims, the Labour Government appointed an interim Aboriginal Land Commissioner, Mr. Justice R. C. Ward, in April 1975 (despite the absence of federal enabling legislation); and finally introduced an aboriginal land rights bill on October 16, 1975. Ironically, Justice Ward's first recommendations for land transfers would reach Parliament on precisely the day the Labour Government fell.

On November 11, 1975, a most extraordinary event occurred in Canberra which effectively killed both the Labour Government's land rights bill and its interim Land Commissioner's recommendations. The repeated refusal of the Opposition-dominated upper house of the federal Parliament to approve the Labour Government's Supply (Appropriations) Bill had caused Prime Minister Whitlam to demand from the Governor General the dissolution of the Senate and new federal elections. ${ }^{11}$ Governor General Sir John Kerr balked at dissolving only one House, and to end the deadlock that followed, Kerr fired Whitlam on November 11th, dissolved both Houses of Parliament, and invited Opposition leader Malcolm Fraser to lead a caretaker government until elections could be held on December 13th. Nothing quite like this had ever occurred in Australia's political history and a furious

38. Anthropologists distinguish between the aboriginal clan that may be called the "owners" of land because they have the right to use the products of the land and also the responsibility to carry out rituals thereon, and the clan with "managerial" responsibilities over the same land. Invariably it is essential that members of both these clans be present before the rituals can be undertaken, and in some cases, "the permission of the 'managers' is necessary for 'owners' to visit their own important sites as well as to conduct rituals associated with them". Long, "Aboriginal Land Rights and Tenure: Past, Present and Future" (Paper delivered to the 20th Australian Survey Congress, Darwin 1977) at 65.

39. See ss. 4 and 5 of the Aboriginal Land Rights (Northern Territory) Amendment Act 1978 (No. 21 of 1978). The delay caused by this drafting confusion led numerous observers to question the good faith of the federal government in carrying out its promises to Aborigines.

40. The Aboriginal Land Fund Act 1974 (No. 159 of 1974) came into effect on Dec. 17, 1974, exactly five months after Woodward's Second Report was submitted to Parliament.

41. Australia has a highly unusual parliamentary system in that, in practice, the federal Prime Minister must retain the confidence of a majority of the members of both houses of the legislature to stay in office. Its constitution impliedly limits the power of the Senate to block enactment of House-approved appropriations bills (Art. 53), but when the Senate rejects or fails to pass money bills, as occurred in 1974 and 1975, the Prime Minister has no alternative but to seek its dissolution and to take his appeal to the electorate. 
debate ensued. ${ }^{42}$ The resulting election found the Liberal Party and its coalition partner, the National Country Party (hereafter referred to as the L/NCP Government), back in political power in Canberra, as they had been in 1972. But from the aboriginal viewpoint this was not a complete return to "square one" since the coalition parties had revised their aboriginal policies during the election and would do so even more once back in office.

In the aboriginal plank of the coalition parties' electoral platform of November 1975, the word "assimilation" had disappeared; Aborigines now could choose whether "to retain their racial identity and traditional life style or where desired to adopt partially or wholly a European life style". ${ }^{43}$ While the statement did not flatly reverse McMahon's refusal to recognize traditional ownership concepts, it pledged to turn over the reserves in the Northern Territory and to acquire lands off the reserves for those "tribal Aborigines living on or near their traditional areas which are not on reserves and [for] detribalized Aborigines in rural or urban areas". And, it added, "in recognizing land rights we shall ensure that the traditional Aboriginal owners gain inalienable title to their lands". ${ }^{4}$ Six months after winning office, the L/NCP governing coalition introduced its own version of the land rights legislation recommended by Woodward. While the Labour Government's land rights legislation had departed somewhat from its Commissioner's proposals, the latest version departed significantly from its predecessor. But the surprising thing was not the changes but the fact that the bill was introduced at all. The proposed land rights legislation indicated that all three major Australian political parties now accepted the legitimacy of aboriginal demands for the preservation of their cultural heritage and were prepared to assist aboriginal "separateness" even to the extent of creating a special landholding system.

Between June 1976, when the new land rights legislation was introduced into Parliament, and December 16, 1976, when the Act passed both houses, some forty-nine amendments were made to the bill. Forty-two of them were made at the request of the Minister who introduced it, R. I. Viner, Minister for Aboriginal Affairs. The effect of some of these amendments was to bring the L/NCP bill closer in form to the Labour Government's bill that had died on November 11,1975; e.g., the authority of the Aboriginal Land Councils to represent aboriginal land claimants was especially augmented. But other differences between the two bills persisted: aboriginal land claims based on need were not included, full aboriginal veto-power over mining was withheld, and several essential matters regarding the extent of the new aboriginal rights were left to the Northern Territory legislature to decide. ${ }^{45}$ Still, it was a most significant government undertaking when it was proclaimed as coming into force on January $26,1977$.

42. By convention in Australia, as in Britain, the Executive exercises authority in name only, being required to obey the orders of the elected Prime Minister and Cabinet. Australia's constitution controversy of 1975 occurred because the Governor General acted contrary to the wishes of the Prime Minister on grounds that those wishes were unconstitutional: Whitlam sought to dissolve only the Senate, while the Constitution (Art. 57) calls for Senate dissolution only in conjunction with the dissolution of the House of Representatives.

43. Liberal and National Country Parties, "Aboriginal Affairs Policy" (1975) at 1.

44. Id..

45. Details of the legislative battle are given in Keon-Cohen, "Aboriginal Land Rights in Australia: Beyond the Legislative Limits?" in Legislation and Societ y in Australia (Tomasic ed. 1980) at 17-19. 


\section{THE ABORIGINAL LAND RIGHTS ACT}

In order to appreciate the full significance of the landholding arrangements made by the 1976 Act, it is necessary to understand the unusual nature of landholding patterns which have developed in large parts of Australia, most especially in the Northern Territory. In contrast to the methods used during the westward expansion of the United States - with individual settlers being allowed to acquire complete ownership to limited amounts of public land without cost (by a simple process of claim subject to minimal use requirements), the remainder of the lands being retained to the present as federally owned, or deeded to the states created out of this vast territory to hold or distribute as they determined - the pattern in Australia was to allow settlers to acquire only a leasehold interest in land for a specific period of years and often for a specific purpose such as mining or pasturing cattle. The old common law concept of Crown ownership of all minerals wherever situated, has been retained virtually throughout Australia (even where land was deeded in fee simple). The explanation for this difference in land policy is said to be that the Australian government has sought to prevent land speculators from being able to acquire vast areas of the country and control their development irrespective of the needs or interests of the country as a whole.

While the leasing policy has gradually given way to outright sale of land in many parts of Australia, leasehold continues to be the pattern in the Northern Territory. Virtually no one in the Territory living outside a municipality has more than a leasehold interest in his land. Rents are often minimal and the leasehold period may vary from thirty years to ninety-nine years. Given the extremely arid nature of the land in much of the Northern Territory (apart from the tropical northern coastline), pastoral leaseholds of enormous size, generally encompassing hundreds of square miles, comprise approximately $70 \%$ of the entire Territory. Roughly $18 \%$ of the Territory consists of federally owned Aboriginal Reserves; and 10\%, generally land so arid as to be unusable even as pasturage, consists of Crown land not yet alienated, i.e., for which no estate or interest, not even a leasehold, has been granted. ${ }^{16}$

The 1976 Land Rights (N.T.) Act marked a radical departure from the prevailing land holding system in that it created a mechanism whereby $18 \%$ of the land in the Northern Territory would be granted in (albeit restricted) fee simple to Aborigines and up to $10 \%$ more of the Territory's land could be so granted in future. Ownership of minerals was excluded and land use and sale restricted. However, this nearly absolute grant of land ownership illustrated the Australian government's recognition that nothing less would do if the land-based culture of the rural Aborigines was to survive, and underlined the government's commitment to fostering aboriginal separateness. However, the mechanism created by the Act was so hedged about by restrictions and was such an undigested juxtaposition of Western legal concepts plus Western ideas about aboriginal legal concepts that its actual impact, both legal and social, on whites and Aborigines in the Northern Territory (and indirectly on the country generally) will take years to become fully apparent. Nonetheless, both its statutory provisions and its 
early years of implementation amply suggest that a dramatic turning point in the relations between whites and Aborigines in Australia occurred with the proclamation of the Act in 1977.

The innovative nature of the 1976 Land Rights Act can best be seen through viewing the three types of legal entities the Act created and their statutory authority. These are the Aboriginal Land Trusts, the Aboriginal Land Councils, and the Aboriginal Land Commissioner.

\section{A. Aboriginal Land Trusts}

The Land Trusts are composed of Aborigines living in the specific areas to be deeded to aboriginal ownership. They shall retain title to individual areas of land in trust for the benefit of those Aborigines who under aboriginal custom and law are entitled to its use or occupation (ss. 4,5). Unlike the laws of some Australian states which similarly established Aboriginal Land Trusts before 1976, the federal act tried to emphasize local aboriginal ownership of local land rather than a single statewide Trust, since the latter was likely to be viewed as continued alien ownership by an aboriginal clan or tribe who view their particular land not as "aboriginal land" but as "our land". The implication of the federal legislation is that local elders will be appointed to each Land Trust created to hold title to a local area. The additional benefit of this localized entity will be that without the need for specific identification by statute, the beneficiaries of the Land Trust will be known to the trustees and vice versa because both will be members of the "local descent group" which comprises the traditional aboriginal owners as specified by the statute (s.3).

The Land Trusts are entirely powerless in practice however, because the statute forbids them from actually exercising any function with relation to the land vested in them except in accordance with directions given by an Aboriginal Land Council; and when such directions are given, they must be obeyed (s.5(2)). Furthermore, Land Trusts are created at the decision of the federal Minister for Aboriginal Affairs, who appoints Trust members from nominations made by the relevant Land Council; Trust members may be removed at any time by the Minister if they fail to act as directed by the Land Council (ss.7, 8). This division of form from function has been explained by an Australian government official who helped draft the Act as intended to handle two very different aspects of land use: traditional aboriginal occupation and modern economic land utilization. ${ }^{47}$ The Land Trust with its traditional elders gives statutory authority for continued traditional land use, while the quite differently constituted Aboriginal Land Councils exist "to deal with new situations created by contract [between] Aboriginals and settlers".48

\section{B. Aboriginal Land Councils ${ }^{49}$}

The Land Councils deal not with traditional Aboriginal use of land but mainly with non-Aboriginal use of land - they will negotiate with mining companies and deal with government bodies wishing to use Aboriginal land for schools, hospitals and provision of other services.

47. Long, supra n. 38 at 65.

48. Id.. In their final statutory form, the Land Trusts were virtually identical to what Woodward had recommended and what the Labour Government had proposed in its land rights legislation in 1975; compare Woodward, Second Report, supra $\mathrm{n}$. 31 at 162-164, with Labour's Aboriginal Land Rights (N.T.) Bill of 1975, and the Aboriginal Land Rights (N.T.) Act 1976, 8s. 4-20.

49. Long, supra n. 38 at 65. 
In contrast to the Land Trusts, the Aboriginal Land Councils are intended to be concerned with a much larger area of land. Only two councils were originally established for the entire Northern Territory, and each is an elected representative body (hence hardly traditional in nature), having numerous land-related functions. ${ }^{50}$ The most specific of these functions are:

(1) that the Land Councils shall negotiate on behalf of the traditional aboriginal owners of land with those outsiders who wish "to use, occupy or obtain an interest in that land" (s.23(1)(e)); and

(2) that they assist Aborigines claiming to have a traditional land claim in pursuing that claim before the Aboriginal Land Commissioner even to the extent of providing free legal assistance (s.23(1)(f)).

In addition, the 1976 Act empowers the Land Councils to "express the wishes" of Aborigines within their area and "protect their interests" as these relate to land (ss.23(1)(a)-(b)), which are functions as much political as they are legal.

On the critical matter of traditional land claims, the authority of Land Councils came full circle from what was proposed by Justice Woodward in 1973 and the Labour Government in 1975, through the legislation proposed by the successor L/NCP Government in June 1976, to the legislation enacted in December 1976. In its final form the Land Rights Act empowered the Land Councils to assist in the espousal of such land claims. This was the result of a legislative struggle that divided the members of the governing coalition of parties and pitted supporters of settler opinion in the Northern Territory against supports of Aborigines. ${ }^{51}$ Given the legal and technical complexity that these land claims would come to represent, it is highly unlikely that any of them could be successfully prepared and argued without the resources available to the Land Councils.

Quite apart from their direct authority over aboriginal lands, it is the wider representative function accorded the Aboriginal Land Councils that makes them so unique. Just as Woodward proposed, the 1976 legislation has for the first time created Western-type governmental bodies with authority to speak and act for Aborigines in the Northern Territory; and even more surprisingly, it has arranged for the almost automatic funding of these bodies through mineral royalty payments, making them capable of exercising their authority with independence. Beyond their role in the settlement of immediate aboriginal demands for land rights, Woodward hoped the Land Councils would become a powerful vehicle for continued aboriginal negotiation with government as times changed and aboriginal demands as well..$^{52}$ Governments rarely create and fund organizations with open-ended authority to press claims against the very authority that created them; but it is difficult to view the Aboriginal Land Councils in Australia's Northern Territory in any other light.

50. The Central and Northern Land Councils were both created by government orders in the fall of 1973, at the request of Woodward J.. They did not become statutory bodies until the passage of the Land Rights Act, see ss. 21-39. A third land council, the Tiwi Land Council, was created by the government on Aug. 28, 1978.

51. Keon-Cohen, supra n. 45 at $\mathbf{1 9 .}$

52. Woodward, Second Report, supra n. 31 at 9-10ff. 


\section{The Aboriginal Land Commissioner}

The third institution or statutory body created by the 1976 Land Rights Act, the Aboriginal Land Commissioner, is the one most altered in appearance from what was recommended in Justice Woodward's report. Woodward had envisioned a multi-member Land Commission of part-time technical experts, not necessarily including judges or lawyers, whose primary function was to make authoritative recommendations to the federal government regarding aboriginal land matters. ${ }^{53}$ The strength of aboriginal traditional claims to land was one matter that the Land Commission would consider but hardly the primary matter since the Commission was to be equally charged with considering where land was needed by aboriginal groups (most notably around towns), even though they could make no tradition-based claim to land. The land rights bill put forward by the Labour Government retained these general recommendatory functions, but reduced the Land Commission to a single Commissioner and strongly suggested that he be a judge. ${ }^{54}$ In the final Act, the Commissioner is required to be a judge of the Supreme Court of the Northern Territory, and his only substantive function is to weigh traditional land claims made by or on behalf of Aborigines (ss.53(1), 50(1)). The consideration of claims based on need has disappeared, and more general recommendatory powers are no longer defined.

Two further provisions limit the authority of the Land Commissioner: he may only consider traditional land claims made to unalienated Crown land in the Northern Territory, or to land in which all interests not held by the Crown are held by, or on behalf of, Aborigines. Against the advantages that may accrue to aboriginal claimants from a favorable recommendation, he must weigh "the detriment to other persons or communities that might result" and the effect which acceding to the claim would have on "existing or proposed patterns of land use in the region" (ss.50(1)(a), 50(3)). In practice, these and other factors that must be considered by the Land Commissioner in making his recommendation to the Minister have turned the claims process into a lengthy quasi-judicial process with months spent in the preparation of legal briefs, the marshalling of evidence by opposing parties and weeks spent in hearing oral arguments. And, perhaps most ironically, the nature of aboriginal traditional land claims, recognized but not codified by the statute, has had to be examined and weighed by an Australian judge in a Western style judicial proceeding.

\section{ABORIGINALS AND MINING}

It is within the sections of the 1976 Act relating to mining that the political compromises inherent in the land rights legislation are most apparent. During the period when aboriginal land rights grew into a major political issue in Australia, so also did enthusiasm for developing newly discovered mineral deposits, especially uranium. As aboriginal reserves as well as lands known to be claimed by Aborigines were discovered to contain major mineral deposits, the fight was joined between those who wanted mineral development to be facilitated as much as possible by government action and those

53. Id. at 129-130, 170-171.

54. Aboriginal Land Rights (N.T.) Bill 1975, ss. 5-8. 
who insisted that aboriginal ownership of land and its minerals (even at the expense of their development) was the more pressing issue. The compromises struck between these two interests satisfied neither and have led to continued tinkering with the Act through amendments. ${ }^{55}$

Two substantial kinds of authority were given to Aboriginal Land Councils with respect to the development of mineral resources on aboriginal land. The Councils could decide to whom licenses for the exploration and recovery of minerals would be issued. They could also decide the terms and conditions (and most notably the royalties to be paid) on such mineral exploitation leases (s.43). However, these two powers were hedged about with some notable exceptions. With regard to licenses, there were two major areas of land already known to contain valuable mineral reserves where the Councils had no authority to refuse mining leases, nor could they prevent mining leases from being granted on any aboriginal land where applications for such had been made before June 4,1976 (s.40). Even where they could decide to grant or refuse a mining lease, the grant required the government's approval while a refusal could be overridden by a proclamation made by the Governor General of Australia declaring that the national interest required that such a grant be made, said proclamation subject to disapproval by resolution of either House of Parliament (ss.40(1)(b), 42).

Even where the Land Councils could not independently refuse to grant a mineral lease, the 1976 legislation did require applicants for such leases to settle the terms, including payments, with the relevant Land Council (s.43). But at the unfettered discretion of the government, an arbitrator may be appointed to settle on terms binding upon both parties whenever the negotiations as to terms of the lease are adjudged by the government to be deadlocked (ss.45, 46). ${ }^{56}$

\section{LAND RIGHTS CLAIMS PRIOR TO IMPLEMENTATION}

While the 1976 land rights legislation established a procedure by which an Aboriginal Land Commissioner would assess aboriginal claims to land based upon traditional ties, such claims had in fact been heard and decided by two appointed bodies before the Aboriginal Land Commissioner began his work.

\section{A. Interim Land Commissioner}

In April 1975, before the grant of any specific statutory authority, the Labour Government appointed Mr. Justice R. C. Ward to act as Interim Aboriginal Land Commissioner, apparently along the lines proposed by

55. See Aboriginal Land Rights (N.T.) Amendment Act 1978(No. 21 of 1978), Aboriginal Land Rights (N.T.) Amendment Act (No. 2) 1978 (No. 70 of 1978), and Amendment Act (No. 3) 1978 (No. 83 of 1978). See also Aboriginal Land Rights Amendment Act 1979 (No. 189 of 1979) and Aboriginal Land Rights Amendment Act 1980 (No. 72 of 1980).

56. While recognizing that anything less than unfettered aboriginal control over mineral exploitation opened the way for a very non-traditional use of aboriginal land, Justice Woodward had recommended that the government retain some final controls over the granting of mineral leases because of the very substantial importance of mining to the national economy of Australia. But he had proposed only the requirement of ministerial approval of Land Council leasing grants and, in extreme cases, the device of a proclamation by the Governor General. Woodward, Second Report, supra n. 31 at 174. The additional limitations on aboriginal authority over mining were added by the L/NCP Government in its version of the Aboriginal Land Rights Act, 1976. 
Justice Woodward's Second Report of the preceding July. Justice Ward was to hear and determine aboriginal land claims and make recommendations to the federal Minister for Aboriginal Affairs, who had the final decisionmaking authority whether or not to grant land for aboriginal ownership. Only four of his reports were ever made public, and these appeared on the same day the Labour Government fell in November 1975. These and his later reports in 1976 may have been in part the impetus for some minor land grants to Aborigines made by the L/NCP Government, but there is insufficient evidence publicly available to assess their importance ${ }^{37}$ His activities were suspended in August 1976 pending completion of the L/NCP land rights legislation, and Justice Ward died in November 1977 after a long period of illness.

It appears that most of Justice Ward's recommendations were based on "needs" claims as permitted by the Woodward Report, but, as noted earlier, this basis for Aboriginal land claims was omitted from the eventual 1976 Act, as was virtually all public mention of Mr. Justice Ward's labors. In the opinion of one knowledgeable observer: ${ }^{68}$

The needs and traditional claims before Ward, J., remain a bizarre, unfinished, and little-known chapter in the land rights story. Tragically, the same "needs" remain - now more acute and less excusable - but the right to claim land on the basis of those needs does not. In addition, at least four reports containing recommendations that land be granted to Aboriginal groups, were forwarded to the Minister of the day, yet four years later, the implementation of those recommendations, some of which at least appear to have been accepted, is still incomplete.

B. Ranger Uranium Inquiry

The first successful aboriginal claim to land in the Northern Territory based on traditional rights came about due to the efforts of a Parliamentary Commission which was charged initially with making very different determinations. The Ranger Uranium Environmental Inquiry was initiated by the federal government on July 17, 1975, to consider both the general question of what the Australian government's policies should be with relation to the mining and exportation of uranium and the specific question of how such mining should be carried on, if at all, in the so-called Ranger area at the "Top End" of the Northern Territory. Very large deposits of uranium ore were discovered in the early 1970's in this area. The inquiry was to be conducted by two commissioners with Mr. Justice R. W. Fox as presiding commissioner.

Uranium became a major political issue in Australia in the early 1970's as the international demand for the mineral increased sharply just when Australia was found to have in its Northern Territory some of the world's most spectacular deposits of uranium. Matters such as nuclear non-proliferation, public health and safety, and environmental impact became intertwined with the issue of aboriginal claims to land where the deposits lay, and government desires to protect the ecologically unique area by creating a national park. The McMahon Government had agreed in November 1972 to permit the development by private corporations of the most promising of these uranium deposits at a place called Jabiru, or Ranger, in the northern end of

57. In Sept. 1979, title to an area of land near Darwin was handed over to the Larrakia Aborigines by the Chief Minister of the Northern Territory; see Aboriginal Newsletter No. 39 (Sept. 7, 1979). This land had been the subject of the Kulaluk land claim heard by Ward J. in May 1975 and recommended for conveyance on June 23, 1975.

58. Keon-Cohen, supra n. $\mathbf{4 5}$ at $\mathbf{2 3}$. 
the Northern Territory close to the western edge of Arnhemland. ${ }^{59}$ But when the Labour Government took office one month later, all uranium development plans were suspended pending a complete review of policies on this delicate and divisive political issue. Two years later, the Labour Government gave a green light to uranium mining again, but only after negotiating for direct government participation in the mining consortium through acquisition of $72 \frac{1}{2} \%$ of Ranger Uranium Mines Pty. Ltd. ${ }^{60}$ Six months after that, the Director of National Parks and Wildlife published a plan to create a national park which would include Ranger and all the other areas sought by mining companies for the development of uranium reserves. Public controversy concerning both governmental actions, especially in light of the still unsettled aboriginal land claims, led to the creation of the Ranger Commission to reconsider the entire matter. By the time the Ranger Commission filed its first report on October 28,1976, the L/NCP coalition was once more in power in Canberra.

In its first report, ${ }^{61}$ the Commission answered a host of questions as to the feasibility as well as the desirability (from the viewpoint of safety as well as practical politics) of developing Australia's uranium deposits. Its basic conclusion was that government should, in conformity with carefully detailed legal and scientific safeguards, proceed to permit and participate in the mining of uranium ore for export. The Commission delayed answering any specific questions concerning mining in the Ranger area for a second report, on the understanding that certain provisions in the government's pending aboriginal land rights legislation would affect its inquiry into aboriginal traditional land claims in the area. When finally approved by Parliament in December 1976, the Land Rights Act did provide that if the Ranger Inquiry made a finding that Aborigines were entitled to the use or occupation of an area of land, that finding would have the same effect as if it were a recommendation made by the Aboriginal Land Commissioner (s.11(3)).

In May 1977, the second report of the Ranger Commission set forth conclusions aimed at satisfying all parties on the issue of land ownership. ${ }^{62}$ The unalienated Crown land surrounding the uranium deposits was adjudged to be entirely aboriginal land, and it was recommended that the government deed it to an Aboriginal Land Trust under the terms of the 1976 Land Rights Act. Two further areas (also containing uranium deposits) held under pastoral leaseholds should, said the Commission, be retaken by the government so that the Aboriginal Land Commissioner could consider traditional aboriginal claims to them. The entire area now or later granted to aborigines should be leased to the Department of National Parks for the creation of Kakadu National Park with substantial aboriginal involvement in its planning, staffing, and management. All uranium mining sites in the area should be included in the lands deeded to aboriginal control (though not in the National Park); but uranium mining was to proceed, at least at the Ranger

59. See Ranger Uranium Environmental Inquiry, Second Report (1977) at 76.

60. Id. at 76-78.

61. Ranger Uranium Environmental Inquiry, First Report (1976).

62. Ranger Inquiry, Second Report at 235-283. 
site, subject to the mining companies and the Aboriginal Northern Land Council successfully negotiating a lease. ${ }^{63}$ Finally, a mining town was to be established near the Ranger site on land within the National Park but not deemed aboriginal land $-a$ town where whites and aboriginals would live together and develop the rich deposits nearby. The federal government accepted these recommendations and amended the 1976 Aboriginal Land Rights Act accordingly during $1978 .{ }^{64}$

\section{CLAIMS BEFORE THE ABORIGINAL LAND COMMISSIONER}

While there have been some thirty traditional land claims presented to the Commissioner, Mr. Justice J. L. Toohey, for consideration, only five had been heard in full and decided by the Commissioner as of the fall of $1980 .^{65} \mathrm{In}$ four of these cases, the Commissioner found the aboriginal claimants to be the traditional owners of virtually the entire unalienated land area claimed, and recommended to the Minister that the claimed lands be conveyed to the Aboriginal Land Trusts for the benefit of the traditional owners. ${ }^{66}$ The Minister for Aboriginal Affairs has accepted these recommendations as written and announced that the transfer of some 95,000 square kilometers in the west central area of the Northern Territory would be made into a Land Trust for Aborigines of the Walpiri and Kartangarurru-Kurintji tribes; and that smaller areas south of Murray Downs pastoral station, adjoining the Ayers Rock National Park, and within the Montejinni pastoral station, totalling some 7,100 square kilometers would be turned over to Land Trusts representing their respective aboriginal traditional owners. ${ }^{67}$

In terms of aboriginal acceptance of the new land rights legislation, however, it is unfortunate that these more recent decisions were preceded by Justice Toohey's May 1978 decision in the Boroloola case. ${ }^{68}$ There was no

63. The aboriginal owners in short could not prevent uranium mining but only negotiate the terms and conditions under which it would take place. These negotiations dragged on until Nov. 1978, as first an American negotiator for the Northern Land Council (N.L.C.) sought to drive the hardest bargain possible with the mining interests, and second, the N.L.C. divided over whether or not to accept the agreement initialed by their negotiator. Negotiations were complicated by the requirement of the Land Rights Act (s.23(3)) that the traditional owners understand and consent to the agreement. See Canberra Times, Sept. 23, 1978, and Age (Melbourne) Nov. 6, 1978.

64. See 106 C.P.D. H. of R. at 650-669 (Aug. 23, 1977). The enabling legislation was contained in Aboriginal Land Rights (N.T.) Amendment Act 1978 (No. 21 of 1978).

65. Four additional claims have been presented to the Commissioner and hearing completed thereon: Utopia Pastoral Station, Willowra Pastoral Station, Limmen Bight and Finniss River. For a discussion of all these claims, completed and pending, see Keon-Cohen, "Land Rights in the Territory: A Progress Report" (1979) 4 Legal Services Bull. at 236-239.

66. See Aboriginal Land Commissioner, Walpiri and Kartangarurru-Kurintji Land Claim, Parl. Paper No. 225 (1978); Alyawarra and Kaititja Land Claim, Parl. Paper No. 103 (1979); Uluru (Ayers Rock) National Park and Lake Amadeus/Luritja Land Claim, Parl. Paper No. 115 (1980); and Yingawunarri (Old Top Springs)Mudbura Land Claim (Apr. 22, 1980).

67. See statements by the Minister for Aboriginal Affairs, 111 C.P.D. H. of R. 1361 (Sept. 26, 1978); 80 C.P.D. Sen. 893 (Mar. 22, 1979); 82 C.P.D. Sen. 1225 (Oct. 19, 1979); and C.P.D. Sen. Whly. Hansard No. 8 at 1639 (1980). In the case of the Uluru (Ayers Rock)Land Claim, the Land Commissioner rejected aboriginal claims to areas lying within the national park on grounds that while still retained by the Crown, these areas had been turned over to the Director of National Parks and were hence effectively alienated, see Uluru Land Claim 33-37.

68. Aboriginal Land Commissioner, Boroloola Land Claim, Parl. Paper No. 123 (1978). See also Parliamentary debate in 109 C.P.D. H. of R. 2600 (May 26, 1978). 
substantial opposition to the aboriginal claimants in the Walpiri, Alyawarra, Uluru, and Yingawunarri cases, and they received (with one exception) substantially what they had claimed. But aboriginal claimants to the unalienated Crown lands surrounding the town of Boroloola and the nearby Pellew Island group in the Gulf of Carpentaria faced opposition from a major mining corporation in much the same kind of confrontation that had marked the Ranger Uranium Inquiry into aboriginal ownership the year before. In marked contrast to the way the Ranger Commissioners treated aboriginal claims, Toohey's Boroloola recommendations strongly favoured the mining corporation and, most regrettably, did so on dubious grounds or on none at all.

By limiting aboriginal land claims to unalienated Crown lands in the Northern Territory, the Australian government had already ensured that only land no one else wanted was eligible for Aborigines to claim. Now it appeared that even land so inhospitable to any agricultural or pastural use that no white farmer or rancher wanted it, might be kept away from its traditional aboriginal owners if it were found to have some commercial value for mining. The Ranger Inquiry resisted the blandishments of mining interests, even ones largely owned by the federal government where the mineral involved was uranium of both national and international importance and the deposit was of immediately exploitable quality. Ranged against this sizeable interest were a tiny group of seventy aboriginal claimants for every 5,000 square kilometers. Yet the Ranger Commissioners decided in their favor, forcing the mining companies to negotiate with the traditional owners and their spokesmen ${ }^{\circ 6}$ But in the Boroloola claim, mining was not currently feasible and would not be until a vast development of transportation and port facilities had been arranged and world market prices had shifted dramatically. Moreover, although the minerals involved were lead and zinc and not uranium, and although there were 250 aboriginal claimants as compared to 70 , Justice Toohey's recommendations served to keep out of aboriginal control just those admittedly aboriginal lands most needed for the future development of the mine. It is through a comparison of the way in which the Ranger Inquiry members approached their task as land commissioners and the approach taken by Toohey as Aboriginal Land Commissioner in the Boroloola case that one can best appreciate the difficulties attendant upon interpreting the central provisions of the Aboriginal Land Rights Act.

As a result of the very considerable rewriting of the land rights legislation from the original Woodward proposals through the Labour Government's draft bill to the draft introduced and then amended by the L/NCP Government in 1976, the functions of the Land Commissioner became both more complicated and more open to differences of interpretation. Rather than simply deciding whether or not a particular piece of unalienated Crown land did belong to a group of Aborigines on the basis of traditional "title" (and then making a recommendation accordingly to the relevant federal Minister), the actual legislation added these further functions to the Land Commissioner's hearing procedure. He was also:

(1) to "have regard to the strength or otherwise of [their] traditional attachments to the land claimed" (s.50(3));

69. Ranger Uranium Environmental Inquiry, Second Report (1977) at 273. 
(2) to "comment on" how many Aborigines would benefit and the extent of their benefit if the claim were granted; and to what extent other "persons or communities" would suffer detriment in consequence (s.50(3)(a)-(c)); and

(3) to "have regard to" the principle that Aborigines living generally where they have a claim but no right, or desiring to live where they have a claim, ought "where practicable, to be able to acquire secure occupancy of that place" (s.50(4)).

The final "principle" would appear to be applicable only where the Land Commissioner might hear an aboriginal claim based on economic need rather than traditional "title", and that authority was eliminated from the Woodward and Labour versions of the legislation by the final L/NCP Government's act. However, Toohey J. relied very heavily upon this "principle" to justify his limiting of lands recommended for transfer to aboriginal ownership, while the Ranger Inquiry virtually ignored this matter.

The aboriginal claimants and the federal government urged both the Ranger Inquiry and $\mathrm{Mr}$. Justice Toohey to make their recommendations on the transfer of land solely on the basis of their findings that the traditional land claims were good. It was argued that the matters set forth in Section 50 of the legislation, to be "commented upon" by the commissioner, should be considered independently of the existence of a valid land claim. ${ }^{70}$ Both the second report of the Ranger Inquiry and the report submitted on Boroloola by Justice Toohey ostensibly adopted this approach. However, in the latter case there is little doubt that detriment to other interests importantly shaped Toohey's recommendations on land transfer to Aborigines. Of the five major islands of the Pellew group claimed by the Aborigines (and recognized by Toohey as validly claimed), only two were recommended for transfer to aboriginal ownership. And while it was concluded that aboriginal claimants had made good their claim to all the unalienated Boroloola lands, the Justice recommended that a corridor be carved out of these lands for the convenience of the Mt. Isa Mining Company in transporting its ores to a port to be built on one of the Pellew islands not to be deeded to aboriginal control. ${ }^{71}$

Even more galling to aboriginal critics of Justice Toohey's Boroloola report was the fact that, while the report was in government hands but before it was released, Mt. Isa Mines bought the pastoral lease to Bing Bong Station, thus securing control of all land between its projected mine and projected port. The delay was critical because local Aborigines had hoped to have the Aboriginal Land Fund Commission acquire the Bing Bong Station lease since it had even greater traditional significance to Aborigines than Boroloola. ${ }^{72}$ The government had prevented the Aboriginal Fund purchase until the Toohey report was acted upon, thus eliminating any possibility of a

70. Aboriginal Land Commissioner, Boroloola Land Claim at 9-13.

71. Id. at 74, 111. Despite the at least quasi-judicial nature of the Land Commissioner's inquiry, the rejection of an aboriginal claim is not final: claimants are not prohibited by the statute from marshalling new evidence and renewing their claims. Hence, claims have been renewed by the N.L.C. to those portions of the Boroloola area not successfully acquired in the first claim proceeding, see Keon-Cohen, supra n. 65 at 239.

72. Bing Bong could not be claimed under the Land Rights Act because being under a pastoral lease it was not unalienated Crown land. 
counter-bid when Mt. Isa Mines chose to move. ${ }^{73}$ Coupled with the fact that Mt. Isa Mines had purchased another adjoining pastoral lease also sought by Aborigines the previous year - by doubling the Aborigines' price of $\$ 400,000$ - the government's behavior in 1978 gave considerable ammunition to those who suggested that in practice the 1976 Land Rights Act would not live up to government promises.

It is important to note that both the Ranger Inquiry and Justice Toohey eschewed the obvious test of occupancy in deciding whether or not a traditional claim to land had been successfully made. ${ }^{74}$ While the evidence was weighed in terms of Western notions of evidence and its sufficiency, the traditional aboriginal basis for land claims was respected. In part, this was because the number of claimants in proportion to the amount of land claimed was so small as to make the doctrine of occupancy ridiculous in application. In part, the land claimed tended to be so remote and inhospitable as virtually to preclude occupancy, and certainly to make it impossible to earn an economic living on the land. But the major reason is that aboriginal land claims are unconnected to occupancy concepts as known in Western law. Each group of descendants of a putative ancestor, whether he be real or mythological, considers itself bound to perform certain ceremonies at, and otherwise preserve, the sacred sites where the ancestor ostensibly travelled and encountered certain adventures during the prehistoric period of the Dreamtime. It is this sense of obligation linking groups to places (even though some places may be rarely visited) that lies at the heart of the traditional land claims and has been translated into Western law terms as equivalent to land ownership. As expressed by the Land Rights Act, traditional aboriginal owners are those who "have common spiritual affiliations to a site on the land, being affiliations that place the group under primary spiritual responsibility for the site and for the land" (s.3(1)).

The evidence put forward and accepted in support of traditional land claims was thus largely oral evidence by the claimants that they could adduce aboriginal names for, and accounts of events linking, geographic locations on the land claimed. Such testimony was strengthened when other Aborigines could be found to agree that the claimants were in fact "affiliated" with the sites and surrounding land and in the manner alleged. The Aboriginal Land Councils made extensive use of the testimony of anthropologists both to convey the specific nature of the "affiliations" asserted by the claimants and to judge the substance of these assertions in terms of aboriginal tradition. Meetings of substantial numbers of aboriginal claimants and non-claimants living on or near the land claimed, were held to discuss the nature and extent of the claimants' land ties; and videotapes of the high degree of concensus reached at these meetings also served as important evidence for the Land Councils' claims.

But what Justice Toohey agreed not to consider for purposes of determining traditional ownership; i.e., occupancy, did strongly affect the recommendations he then chose to make to the Minister in the Boroloola claims

73. Newspaper reports in Australia noted that the federal Dept. of Aboriginal Affairs knew of the projected lease purchase by Mt. Isa Mines but did not inform the Aboriginal Land Fund Commission until it was too late, see Morning Herald (Sydney) May 26, 1978 at 6.

74. Ranger Inquiry, Second Report 267; Boroloola Land Claim supra n. 68 at 45. 
case. As previously noted, under the Land Rights Act the Land Commissioner is required to "have regard to the strength or otherwise" of the claimants' "traditional attachments to the land claimed" (s.50(3)); and to "have regard to" the principle that Aborigines should be allowed to acquire secure occupancy of that place where they desire to live (s.50(4)). The Ranger Inquiry said virtually nothing with regard to the latter principle and effectively threw up their hands at trying to weigh the strength of traditional attachment, concluding simply that the attachment was sufficient even though few claimants lived on the lands claimed and future "aboriginal use or occupation will probably be minimal". ${ }^{75}$ Justice Toohey, however, took similar findings (none of the Boroloola claimants lived on the lands claimed and few would do more than occasionally visit if they were accorded title to the lands) and apparently concluded, although no such reasoning is set forth in his report, that "having regard to" these facts, he was warranted in recommending that only some of the lands adjudged aboriginal should actually be conveyed to Aboriginal Land Trusts. ${ }^{76}$

\section{CONCLUSION}

As a consequence of aboriginal political pressures felt by all national political parties in Australia in the wake of the Milirrpum decision of 1971, a legal mechanism has been created for the first time in Australia's history to translate traditional aboriginal land claims into the fee simple concept of ownership known under Western law. As limited and imperfect as the Aboriginal Land Rights Act of 1976 is, its consequence will likely be that in the near future as much as 750,000 square miles of the Northern Territory will come under full aboriginal ownership. And through the aegis of the Aboriginal Land Councils with their assured income from mineral royalties, aboriginal interests in the Northern Territory will become an increasingly significant political force which should lead to further legal and political rights being accorded to Aborigines in the Territory. As an example of what can and should be done in recognition of aboriginal land demands, both from the social perspective and as a matter of justice, the federal land rights legislation has already had an impact on the Australian states, and this is likely to grow."

But the federal legislation is hardly a complete answer even to the land demands of Aborigines in the Northern Territory. It offers nothing by way of compensation to those Aborigines who cannot claim land, and to those with valid claims it offers title only to the most desolate land in the Territory. Where title is sought to land already alienated, the only hope is that government will purchase the leasehold interests and give these to the claimants or at least take back the leased interest so as to permit an aboriginal land claim

75. Ranger Inquiry, Second Report 267-268.

76. Boroloola Land Claim, supra n. 68 at 44-57.

77. In South Australia the legislative process of establishing a special Aboriginal Land Trust for the Pitjantjatjara peoples modelled on the federal land trust idea has proceded fitfully. And in New South Wales legislation is likely to be introduced soon and will more or less follow the federal precedent. In contrast, in Queensland where the state government has moved to end any special status for Aborigines, federal legislation has at least given to aboriginal residents of two discontinued Reserves a degree of self-government. 
to be heard by the Aboriginal Land Commissioner. ${ }^{78}$ Even here, when commercial interests want the same leases, they may almost always outbid or outmanoeuvre the Aboriginal Land Fund or its successor agency, as they did in the area around Boroloola.

Finally, the 1976 Land Rights Act is likely to be the last as well as the first Australian federal endeavor in support of aboriginal land claims for the foreseeable future. The federally administered Northern Territory took a major step towards statehood on July 1,1978, with a corresponding reduction in the degree of federal controls. ${ }^{79}$ While the Land Rights Act continues to be law in the Territory, the territorial administration has already taken steps to further limit its area of application, and has continued to successfully block the actual transfer of any lands to aboriginal control. Most recently this has been achieved by insisting that public roads through aboriginal lands must be surveyed before land transfers can be recorded and thereby come into effect. ${ }^{80}$ Despite the authority over aboriginal affairs accorded the federal government by the 1978 Referendum, there have been few steps taken to legislate for Aborigines outside the Northern Territory, and of these the only successful ones so far have been premised on state cooperation. With the Northern Territory on the verge of full statehood, there is little chance that the federal government will choose to enact further legislation for the territory with anything like the sweep of the 1976 Land Rights Act. Future steps in the area of aboriginal land rights will have to be taken by individual states, a slow and fragmented process; or will have to await the election of an Australian government willing to make use of the authority now accorded it in the constitution to "grasp the nettle [of aboriginal land rights] firmly".

78. While the Queensland government has prevented any leaseholds in that state from being purchased by the Aboriginal Land Fund, 60 pastoral leaseholds elsewhere in Australia have been bought by the Fund for aboriginal use, see 5 Commonwealth Record 989 July 7-13, 1980). Two further leases are scheduled to be taken up by the government to allow aboriginal land claims to be made to the remainder of the Ranger area. The Australian High Court ruled in Feb. 1980 that aboriginal land claims in fee simple could be made where all leasehold interests were held by a government agency on behalf of Aborigines, see $R$. v. Toohey ex parte Attorney-General (N.T.) [1980] A.C.L.D. 144.

79. See Northern Territory (Self Government) Act 1978 (No. 58 of 1978).

80. See Keon-Cohen, supra n. 65 at 237, 240. The federal government has assured Aborigines however that "non-registration did not affect the validity of the title deeds granted by the Governor General", see Dept. of Aboriginal Affairs, Report for 1978.79 (1979) at 6. 